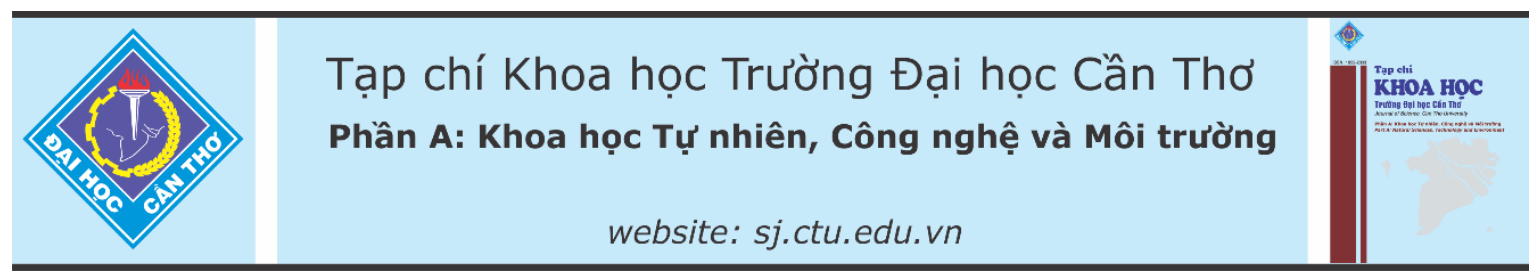

DOI:10.22144/ctu.jvn.2021.039

\title{
MÔ HİNH CHUỘT Mus musculus VIÊM LOÉT DẠ DÀY BỞI ETHANOL, ACETIC ACID VÀ ASPIRIN
}

Phan Thành Đạt, Lâm Vĩ Nhã, Nguyễn Nguyền Trân, Phùng Thị Hằng và

Nguyễn Trọng Hồng Phúc*

Khoa Su pham, Truòng Đại học Cần Tho

*Nguời chịu trách nhiệm về bài viết: Nguyễn Trọng Hồng Phúc (email: nthphuc@ctu.edu.vn)

\section{Thông tin chung:}

Ngày nhận bài: $16 / 11 / 2020$

Ngày nhận bài sủa: 17/02/2021

Ngày duyệt đăng: 28/04/2021

\section{Title:}

Stomach ulcer Mus musculus mice model by alcohol, acetic acid and aspirin

\section{Tù khóa:}

Acetic acid, Aspirin, Ethanol, mô hình loét dạ dày

\section{Keywords:}

Acetic acid, Alcohol, Aspirin, Stomach ulcer model.

\begin{abstract}
Stomach ulcers are a common gastrointestinal disease and there have been many studies and strategies to prevent this disease. Many studies have been done subclinical and clinical to find preventive drugs, but the animal model of stomach ulcers has not been agreed. This study was performed to evaluate 3 models of acute gastric ulcer in Mus musculus by ethanol $\left(60^{\circ}, 70^{\circ}\right.$ and $\left.80^{\circ}\right)$, acetic acid $(10 \%, 15 \%$ and $20 \%)$ and aspirin $(350 \mathrm{mg} / \mathrm{kg}, 500 \mathrm{mg} / \mathrm{kg}$ and $650 \mathrm{mg} / \mathrm{kg}$ ) with the evaluation criteria of total acidity, ulcer index by depth, length and area of the ulcer. The results showed that all 3 ulcer agents could cause stomach ulcers, in which $70^{\circ}$ ethanol, $10 \%$ acetic acid and $500 \mathrm{mg} / \mathrm{kg}$ Aspirin were suitable agents to make stomach ulcer mice models.
\end{abstract}

\section{TÓM TÁtT}

Viêm loét da dày là bệnh đường tiêu hóa phổ biến và đã có nhiều nghiên cứu, phát đồ phòng trị bệnh này. Nhiều nghiên cưu được thưc hiện cận lâm sàng và lâm sàng nhằm tìm ra các loại thuốc phòng trị nhung mô hình động vật bị loét da dày vẫn chura được thống nhất. Nghiên cứu này thực hiện khảo sát 3 mô hình loét dạ dày cấp tính trên chuột nhắt trắng Mus musculus bởi ethanol $\left(60^{\circ}, 70^{\circ}\right.$ và $\left.80^{\circ}\right)$, acetic acid $(10 \%, 15 \%$ và $20 \%)$ và aspirin $(350 \mathrm{mg} / \mathrm{kg}, 500 \mathrm{mg} / \mathrm{kg}$ và $650 \mathrm{mg} / \mathrm{kg})$ với các chỉ tiêu đánh giá về tổng độ acid, chỉ số loét theo độ sâu, chiều dài và diện tích vết loét. Kết quả cho thấy cả 3 tác nhân gây loét đều có thể gây loét cấp da dày, trong đó, ethanol $70^{\circ}$, acetic acid $10 \%$ và aspirin $500 \mathrm{mg} / \mathrm{kg}$ là các tác nhân phù hợp để xây dựng mô hình gây loét dạ dày cấp tính.

\section{GIỚI THIỆU}

Viêm loét dạ dày là bệnh rối loạn tiêu hóa phổ biến, ảnh hưởng đến 4 triệu người trên thế giới hàng năm, với tỷ lệ mắc bệnh ước tính khoảng $1,5 \%$ đến 3\% (Zelickson et al., 2011; Zittel et al., 2000). Lạm dụng rượu, hút thuốc lá, căng thẳng, sử dụng thuốc chống viêm không steroid (NSAID) và nhiễm vi khuẩn Helicobactor pylori là những nguyên nhân phổ biến gây viêm loét dạ dày (Kim et al., 2014). Loét xảy ra do sự mất cân bằng giữa acid dạ dàypepsin và yếu tố bảo vệ niêm mạc (Søreide et al.,
2015). Bệnh thường tái phát, có nhiều biến chứng nguy hiểm, trường hợp loét nặng có thể gây xuất huyết dạ dày và tử vong (Chan \& Leung, 2002).

Nhiều loại thuốc hóa học đã được tổng hợp sử dụng để điều trị loét dạ dày như làm giảm tiết acid dạ dày, trung hòa tiết acid dạ dày, bảo vệ niêm mạc thành dạ dày hay sử dụng thuốc kháng sinh (Nihar et al., 2017). Các loại thuốc này mặc dù được chứng minh là có hiệu quả trong việc điều trị dạ dày nhưng cũng tạo ra nhiều tác dụng phụ nghiêm trọng và giá thành cao hơn so với sử dụng thuốc có nguồn gốc từ 
thực vật (Wariss et al., 2013). Với sự gia tăng nghiên cứu và ứng dụng thảo dược trong điều trị viêm loét dạ dày, các mô hình động vật thử nghiệm với các vết loét khác nhau để đánh giá khả năng bảo vệ dạ dày cũng đang được phát triển. Tuy nhiên, mô hình loét dạ dày được sử dụng cho các nghiên cứu phát triển thuốc bảo vệ dạ dày còn nhiều tranh luận (Singer et al., 1987) và hạn chế (Adinortey et al., 2013). Cồn trong rượu bia (Pöschl \& Seitz, 2004), các loại thực phẩm ngâm chua (Ren et al., 2012) và tác dụng phụ của thuốc (Akre et al., 2001) là các tác nhận chủ yếu gây ra viêm loét dạ dày tá tràng. Do đó, nghiên cứu này, thực hiện khảo sát các mô hình gây loét dạ dày cấp tính trên chuột nhắt trắng được gây loét bằng ethanol, acetic acid và aspirin với các chỉ tiêu đánh giá mức độ loét và mức độ phục hồi cụ thể, nhằm xác định mô hình loét dạ dày cấp tính với tác nhân và nồng độ gây loét phù hợp cho việc nghiên cứu phát triển các loài thảo dược trong phòng trị loét dạ dày.

\section{PHƯƠNG PHÁP NGHIÊN CÚU}

\section{1. Đối tượng và phương pháp bố trí thí nghiệm}

Chuột nhắt trắng Mus musculus đực trưởng thành, sạch bệnh, trọng lượng 25-30 g được cung cấp bởi viện Pasteur - TP. Hồ Chí Minh và được nuôi thuần tại phòng thí nghiệm Sinh lý động vật Bộ môn Sư phạm Sinh học, Trường Đại học Cần Thơ trong điều kiện sáng/tối 12:12 giờ.

Chuột ở tất cả các nghiệm thức đều cho nhịn ăn 24 giờ trước khi thử nghiệm, uống nước tự do (Kim et al., 2019). Sau 24 giờ, thử nghiệm đối với từng tác nhân gây loét gồm gây loét bằng ethanol $(\mathrm{Al}$ et al., 2008; Rahim et al., 2014; Sattar et al., 2019), acetic acid (Somchit et al., 2007) và aspirin (Adefisayo et al., 2017 ; Gul et al., 2015). Chuột thí nghiệm được chia thành 7 nghiệm thức tương ứng với mỗi loại tác nhân gây loét, mỗi nghiệm thức có 3 chuột. Trong đó, nghiệm thức 1 là nghiệm thức đối chứng sinh học (ĐCSH); nghiệm thức 2,3 và 4 là nghiệm thức thử nghiệm gây loét tương ứng với mỗi loại tác nhân; nghiệm thức 5,6 và 7 là nghiệm thức đối chứng dương với thuốc phòng trị loét dạ dày Omeprazole $20 \mathrm{mg} / \mathrm{kg}$ (MEPRAZ, Sanofi - Pháp) (Al-bayati et al., 2015; Raeesi et al., 2019) có bán trên thị trường thông qua cơ chế ức chế bơm $\mathrm{H}^{+} / \mathrm{K}^{+}$ATPase (Madi \& Abd al-Barr, 2014). Cách bố trí thí nghiệm được trình bày ở Bảng 1 . Thể tích dung dịch mỗi lần chuột nhận là $5 \mathrm{~mL} / \mathrm{kg}$ (Ahmed et al., 2013). Sau 1 giờ gây loét, các chuột thí nghiệm được gây mê, hủy tủy và giải phẫu để phân tích.

Bảng 1. Các bước thực hiện loét dạ dày trên mô hình loét bằng ethanol, acetic acid và aspirin

\begin{tabular}{|c|c|c|c|}
\hline Nghiệm thức & Bắt đầu & Giai đoạn 1 (Sau 1h) & Giai đoạn 2 (Sau 1h) \\
\hline \multicolumn{4}{|c|}{ Mô hình sử dụng ethanol } \\
\hline ĐCSH & Uống nước cất & Uống nước cất & \multirow{7}{*}{ Lấy chỉ tiêu đánh giá } \\
\hline E60 & Uống nước cất & Uống ethanol $60^{\circ}$ & \\
\hline E70 & Uống nước cất & Uống ethanol $70^{\circ}$ & \\
\hline E80 & Uống nước cất & Uống ethanol $80^{\circ}$ & \\
\hline $\mathrm{E} 60+\mathrm{O}$ & Uống Omeprazole & Uống ethanol $60^{\circ}$ & \\
\hline $\mathrm{E} 70+\mathrm{O}$ & Uống Omeprazole & Uống ethanol $70^{\circ}$ & \\
\hline $\mathrm{E} 80+\mathrm{O}$ & Uống Omeprazole & Uống ethanol $80^{\circ}$ & \\
\hline \multicolumn{4}{|c|}{ Mô hình sử dụng acetic acid } \\
\hline ĐCSH & Uống nước cất & Uống nước cất & \multirow{7}{*}{ Lấy chỉ tiêu đánh giá } \\
\hline A10 & Uống nước cất & Uống acetic acid $10 \%$ & \\
\hline A15 & Uống nước cất & Uống acetic acid $15 \%$ & \\
\hline A20 & Uống nước cất & Uống acetic acid $20 \%$ & \\
\hline $\mathrm{A} 10+\mathrm{O}$ & Uống Omeprazole & Uống acetic acid 10\% & \\
\hline $\mathrm{A} 15+\mathrm{O}$ & Uống Omeprazole & Uống acetic acid 15\% & \\
\hline $\mathrm{A} 20+\mathrm{O}$ & Uống Omeprazole & Uống acetic acid $20 \%$ & \\
\hline \multicolumn{4}{|c|}{ Mô hình sử dụng Aspirin } \\
\hline ĐCSH & Uống nước cất & Uống nước cất & \multirow{7}{*}{ Lấy chỉ tiêu đánh giá } \\
\hline As350 & Uống nước cất & Uống Aspirin $350 \mathrm{mg} / \mathrm{kg}$ & \\
\hline As500 & Uống nước cất & Uống Aspirin $500 \mathrm{mg} / \mathrm{kg}$ & \\
\hline As650 & Uống nước cất & Uống Aspirin $650 \mathrm{mg} / \mathrm{kg}$ & \\
\hline As $350+O$ & Uống Omeprazole & Uống Aspirin $350 \mathrm{mg} / \mathrm{kg}$ & \\
\hline As $500+O$ & Uống Omeprazole & Uống Aspirin $500 \mathrm{mg} / \mathrm{kg}$ & \\
\hline As $650+O$ & Uống Omeprazole & Uống Aspirin $650 \mathrm{mg} / \mathrm{kg}$ & \\
\hline
\end{tabular}




\subsection{Các chỉ số phân tích}

\section{Tổng độ acid}

Dịch dạ dày được pha loãng với $200 \mu \mathrm{L}$ nước cất trong tuýp nhựa $1,5 \mathrm{~mL}$, sau đó ly tâm 3.000 vòng/phút trong 1 phút. Thu nhận $100 \mu \mathrm{L}$ dịch nổi và trộn đều với $20 \mu \mathrm{L}$ phenolphthalein. Dung dịch này được chuẩn độ bằng $\mathrm{NaOH} 0,01 \mathrm{~N}$ cho đến khi xuất hiện màu hồng vĩnh viễn. Tổng độ acid được tính theo công thức (Abebaw et al., 2017; Jabeen, 2018; Reddy et al., 2012): Tổng độ acid = $\frac{V_{N a O H} \times N \times 100 \mathrm{mEq} / \mathrm{L}}{0,1}$

0,1

Với $\mathrm{V}_{\mathrm{NaOH}}$ là thể tích $\mathrm{NaOH}$ đã dùng để trung hòa và $\mathrm{N}$ là nồng độ đương lượng của $\mathrm{NaOH}$.

\section{Chỉ số loét}

Dạ dày sau khi lấy dịch dạ dày được mở theo bờ cong lớn. Rửa sạch bằng nước cất để loại bỏ các chất trong dạ dày và quan sát bằng kính lúp để đo diện tích dạ dày, diện tích vết loét, độ dài vết loét theo phương pháp của Dashputre and Naikwade (2011) và độ sâu vết loét theo phương pháp của Reddy et al. (2012) và Oluwabunmi and Abiola (2015).

Chỉ số loét Ulcer ( $\left.\mathrm{UI}_{\text {Dài/Sâu }}\right)$ được tính theo công thức: $\mathrm{UI}=\left(\mathrm{U}_{\mathrm{n}}+\mathrm{U}_{\mathrm{s}}+\mathrm{U}_{\mathrm{p}}\right) \times 10^{-1}$ (Abebaw et al., 2017). Trong đó, $U_{n}$ là số vết loét trung bình trên mỗi động vật; $\mathrm{U}_{\mathrm{s}}$ là chỉ số loét theo mức độ loét; và $\mathrm{U}_{\mathrm{p}}$ là tỉ lệ phần trăm động vật bị loét trong lô chuột.

Chỉ số Ulcer ( $\mathrm{UI}_{\text {Diện tich }}$ ) được tính theo công thức (Ozbakiş et al., 2005):

$$
\mathrm{UI}_{\text {Diện tích }}=\frac{\text { diện } \text { tích loét }}{\text { diện tích dạ dày }} \times 100
$$

Hiệu suất bảo vệ dạ dày được tính theo công thức (Kamarolzaman et al., 2014):

$$
\text { \% bảo vệ }=\frac{U I \text { (Đối chứng bệnh) }-U I \text { (Điều trị bệnh) }}{U I \text { (Đối chứng bệnh) }}
$$

\section{Mô học}

Dạ dày sau khi đo vết loét được cố định trong dung dịch formol đệm $10 \%$, rửa nước, khử nước, tẩm paraffin và đúc khuôn để cắt mẫu. Mẫu dạ dày được cắt bằng máy cắt Microtome (Sakura, Nhật) có độ dày $5 \mu \mathrm{m}$ và nhuộm kép với Hematoxylin và Eosin theo quy trình chuẩn của Bộ Y tế (2016).

\subsection{Phương pháp xử lí thống kê}

Số liệu nghiên cứu được lưu trữ và phân tích bằng phần mềm Minitab 17 (LEAD Technologies, Inc.; Mỹ). Trước khi thực hiện các phép so sánh, các dãy số liệu đều được kiểm tra tính phân phối chuẩn bằng Anderson-Darling và được quy đồi nếu phân phối chưa chuẩn. Các trung bình được so sánh bằng OneWay ANOVA với post hoc Fisher ở độ tin cậy $95 \%$.

\section{KẾT QUẢ VÀ THẢO LUẬN}

\subsection{Mô hình viêm loét dạ dày bằng ethanol}

Sự hiện diện của ethanol với nồng độ càng cao thì càng có xu hướng làm giảm tổng độ acid trong dạ dày. Chuột uống ethanol các nồng độ $60^{\circ}, 70^{\circ}$, $80^{\circ}$ có tổng độ acid lần lượt là $3,07 \pm 0,51 \mathrm{mEq} / \mathrm{L}$; $2,13 \pm 0,25 \mathrm{mEq} / \mathrm{L}$ và $1,24 \pm 0,19 \mathrm{mEq} / \mathrm{L}$ (Hình 1 ) trong khi tổng acid của dạ dày chuột đối chứng sinh học là $3,8 \pm 0,53 \mathrm{mEq} / \mathrm{L}$. Kết quả nghiên cứu này phù hợp với công bố của Chari et al. (1993), nồng độ ethanol thấp gây kích thích tế bào giải phóng gastrin từ đó làm giảm $\mathrm{pH}$. Ngược lại, khi nồng độ độ ethanol cao sẽ ức chế tế bào phóng thích gastrin dẫn đến sự suy giảm tổng độ acid dần qua các nồng độ ethanol $(\mathrm{p}<0,05)$.

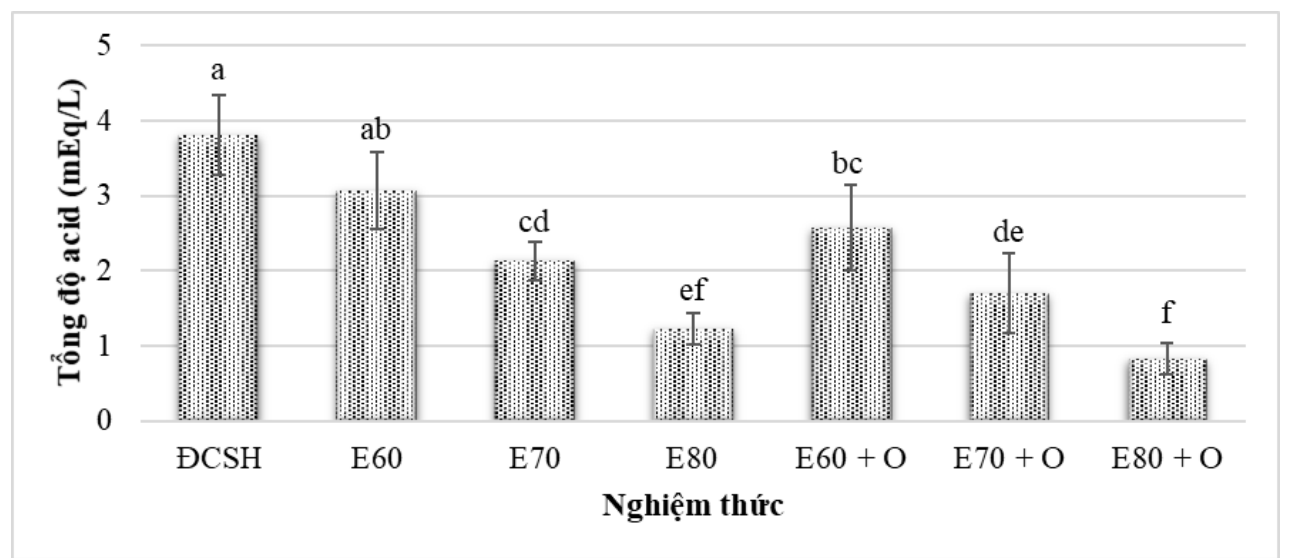

Hình 1. Chỉ số tổng độ acid của các nghiệm thức gây loét bằng ethanol

Các cột trung bình \pm sai số chuẩn có các chũ cái giống nhau thì khác biệt không có ý nghĩa thống kê (Fisher, $p>0,05)$. 
Các nghiệm thức chuột được cho uống Omeprazole để bảo vệ dạ dày có xu hướng giảm so với nghiệm thức không được bảo vệ ở các nồng độ ethanol tương ứng, tuy nhiên sự khác biệt này không có ý nghĩa thống kê $(p>0,05)$. Như vậy, chuột được bảo vệ dạ dày bằng Omeprazole có tổng độ acid không có sự khác biệt với chuột uống ethanol. Kết quả này phù hợp với thí nghiệm trước đó của Singer et al. (1987). Điều này được lý giải do Omeparzole có vai trò làm giảm dịch vị bằng cách tăng $\mathrm{pH}$ dạ dày (Goddard \& Spiller, 1996). Qua phân tích, đối với tác nhân gây loét dạ dày cấp tính bằng ethanol, tổng độ acid không thể hiện sự khác biệt giữa đối chứng dương và đối chứng âm khi sử dụng ethanol nồng độ cao, vì thế không mang tính khả thi khi sử dụng chỉ số này để đánh giá.

Nghiên cứu đã thực hiện đánh giá mức độ loét và bảo vệ qua các chỉ số loét (UI) theo chiều dài vết loét, độ sâu vết loét và diện tích vết loét. Kết quả cho thấy chỉ số $U_{\text {Dài }}$ và UI Sâu giữa nghiệm thức chuột bị loét và nghiệm thức được bảo vệ không có sự khác biệt ( $p$ > 0,05) (Bảng 2). Chỉ số UI xét theo độ sâu vết loét không thể hiện sự khác biệt giữa các nghiệm thức có thể do phương pháp này được đánh giá bằng hình thức quan sát mức độ loét của dạ dày và không có quy chuẩn cụ thể nên dễ gây ra sai lệch khi cho mức độ thang điểm. Trong khi đó, kết quả UI xét theo diện tích vết loét thể hiện rõ sự khác biệt giữa các nghiệm thức, dạ dày chuột uống ethanol $70^{\circ}$ được bảo vệ bằng Omeprazol có giá trị UI giảm rõ so với uống ethanol $70^{\circ}$ từ $12,57 \pm 5,23$ còn $1,95 \pm 0,75(\mathrm{p}<0,05)$. Tương tự đối với nghiệm thức uống ethanol $80^{\circ}$ và được bảo vệ giảm từ $18,48 \pm 3,89$ còn $8,65 \pm 4,08(\mathrm{p}<0,05)$. Hiệu quả bảo vệ dạ dày

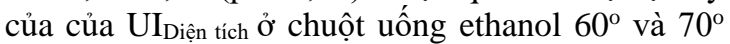
tương đương nhau lần lượt là $89,18 \%$ và $84,49 \%$, ngược lại do ethanol $80^{\circ}$ có nồng độ cao làm cho khả năng bảo vệ dạ dày của Omeprazole giảm nên gây ra vết loét lớn, vì thế hiệu suất bảo vệ chỉ giảm còn $53,19 \%$. Qua những phân tích trên, chỉ số UI sâu và UIDài không cho thấy tính khả thi khi sử dụng để đánh giá mức độ loét dạ dày bởi ethanol, trong khi

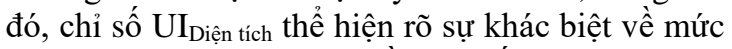
độ loét và khả năng phục hồi của đối chứng dương. Đồng thời, khi sử dụng ethanol $70^{\circ}$ làm tác nhân gây loét dạ dày cấp tính, trị số $\mathrm{UI}_{\text {Diện tích và hiệu suất bảo }}$ vệ dạ dày giữa nghiệm thức không được bảo vệ và được bảo vệ bởi Omeprazole thể hiện rõ sự khác nhau. Như vậy, ethanol $70^{\circ}$ là nồng độ ethanol phù hợp để thực hiện mô hình loét dạ dày cấp tính.

Bảng 2. Chỉ số loét và hiệu suất bảo vệ dạ dày gây ra bởi tác nhân gây loét ethanol

\begin{tabular}{lrrrrrr}
\hline Nghiệm thức & UISâu & $\begin{array}{r}\text { Hiệu suất } \\
\text { bảo vệ (Sâu) }\end{array}$ & UIDài & $\begin{array}{r}\text { Hiệu suất bảo } \\
\text { vệ (Dài) }\end{array}$ & UIDiện tích & $\begin{array}{r}\text { Hiệu suất bảo vệ } \\
\text { (Diện tích) }\end{array}$ \\
\hline ĐCSH & $0,00 \pm 0,00^{\mathrm{d}}$ & $100,00 \%$ & $0,00 \pm 0,00^{\mathrm{c}}$ & $100,00 \%$ & $0,00 \pm 0,00$ & $100,00 \%$ \\
$\mathrm{E} 60$ & $0,35 \pm 0,05^{\mathrm{b}, \mathrm{c}}$ & - & $0,53 \pm 0,12^{\mathrm{a}, \mathrm{b}}$ & - & $5,36 \pm 1,59^{\mathrm{c},}$ & - \\
$\mathrm{E} 70$ & $0,50 \pm 0,05^{\mathrm{a}, \mathrm{b}}$ & - & $0,70 \pm 0,10^{\mathrm{a}}$ & - & $12,57 \pm 5,23$ & - \\
$\mathrm{E} 80$ & $0,55 \pm 0,05^{\mathrm{a}}$ & - & $0,73 \pm 0,06^{\mathrm{a}}$ & - & $18,48 \pm 3,89$ & - \\
$\mathrm{E} 60+\mathrm{O}$ & $0,16 \pm 0,25^{\mathrm{c}, \mathrm{d}}$ & $88,89 \%$ & $0,24 \pm 0.40^{\mathrm{b}, \mathrm{c}}$ & $54,72 \%$ & $0,58 \pm 1,0^{\mathrm{d},}$ & $89,18 \%$ \\
$\mathrm{E} 70+\mathrm{O}$ & $0,45 \pm 0,09^{\mathrm{a}, \mathrm{b}}$ & $40,43 \%$ & $0,63 \pm 0,12^{\mathrm{a}}$ & $10,00 \%$ & $1,95 \pm 0,75^{\mathrm{d},}$ & $84,49 \%$ \\
$\mathrm{E} 80+\mathrm{O}$ & $0,50 \pm 0,09^{\mathrm{a}, \mathrm{b}}$ & $35,48 \%$ & $0,70 \pm 0,10^{\mathrm{a}}$ & $4,11 \%$ & $8,65 \pm 4,08^{\mathrm{b},}$ & $53,19 \%$ \\
\hline
\end{tabular}

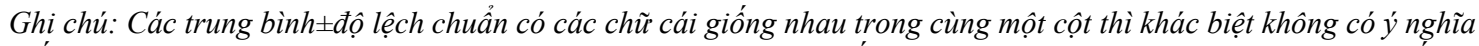
thống kê (Fisher, $p>0,05$ ). Chú thích '- 'nghĩa là không sủ dụng chất bảo vệ dạ dày nên không tính toán hiệu suẩt bảo vê.

Kết quả quan sát hình thái dạ dày của các nghiệm thức cho thấy, chuột uống ethanol $60^{\circ}$ dạ dày loét ít, hiện tượng xuất huyết dạ dày thể hiện không rõ. Chuột uống ethanol $60^{\circ}$ được bảo vệ dạ dày bằng Omeprazole hầu như không cho thấy sự xuất huyết dạ dày, do đó, kết quả xác định chỉ số loét UI $I_{\text {Diện tích }}$ giữa nghiệm thức uống ethanol $60^{\circ}$ và được bảo vệ bằng Omeprazole không cho thấy sự khác biệt (Hình 2). Nghiệm thức chuột uống ethanol $70^{\circ}$ và $80^{\circ}$ thể hiện rõ các vết loét rộng trên niêm mạc dạ dày và gây xuất huyết ở một số vị trí. Nghiệm thức uống ethanol $70^{\circ}$ và $80^{\circ}$ được bảo vệ bằng Omeprazole giảm diện tích vết loét và xuất huyết, tuy nhiên, dạ dày chuột ở nghiệm thức uống ethanol $80^{\circ}$ được bảo vệ bằng Omeprazole giảm ít hơn so với nghiệm thức chuột uống ethanol $70^{\circ}$. Do chuột uống uống ethanol $80^{\circ}$ có nồng độ ethanol cao gây ra vêt loét rộng và xuất huyết nhiều nên Omeprazole không thể hiện được khả năng bảo vệ dạ dày khi so sánh với mô hình chuột sử dụng ethanol $70^{\circ}$. 


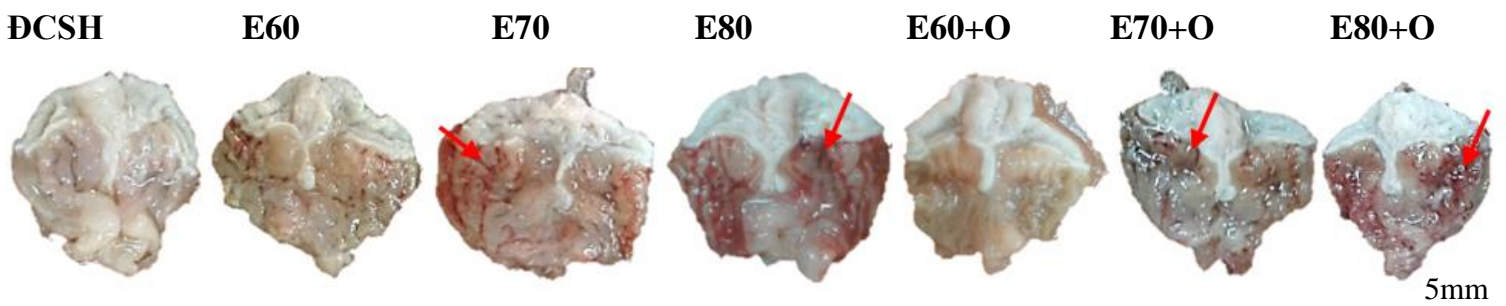

Hình 2. Hình thái dạy dày chuột bị loét cấp tính do ethanol ở các nồng độ khác nhau và được bảo vệ bằng Omeprazol.

Ghi chú: Mũi tên: vị trí xuất huyết.

Quan sát mô học cho thấy, nghiệm thức ĐCSH các tế bào niêm mạc sắp xếp đều thành dãy, không thấy hiện tượng xuất huyết dạ dày (Hình 3-A). Chuột uống ethanol $60^{\circ}$ và $70^{\circ}$ lớp niêm mạc dạ dày bị bong tróc và bị hoại tử (Hình $3-\mathrm{B}, 3-\mathrm{C}$ ), chuột uống ethanol $80^{\circ}$ bị bong tróc ăn sâu vào lớp cơ với nhiều vị trí xuất huyết (Hình 3-D). Nghiệm thức chuột uống ethanol $60^{\circ}$ và $70^{\circ}$ được bảo vệ bằng Omeprazole niêm mạc dạ dày giảm sự bong tróc và hoại tử tế bào so với nghiệm thức không được bảo vệ (Hình 3-E, 3-F). Dạ dày được bảo vệ bằng Omeprazole hầu như không cho thấy khả năng làm giảm bong tróc khi bị ảnh hưởng bởi ethanol $80^{\circ}$ (Hình 4-G).

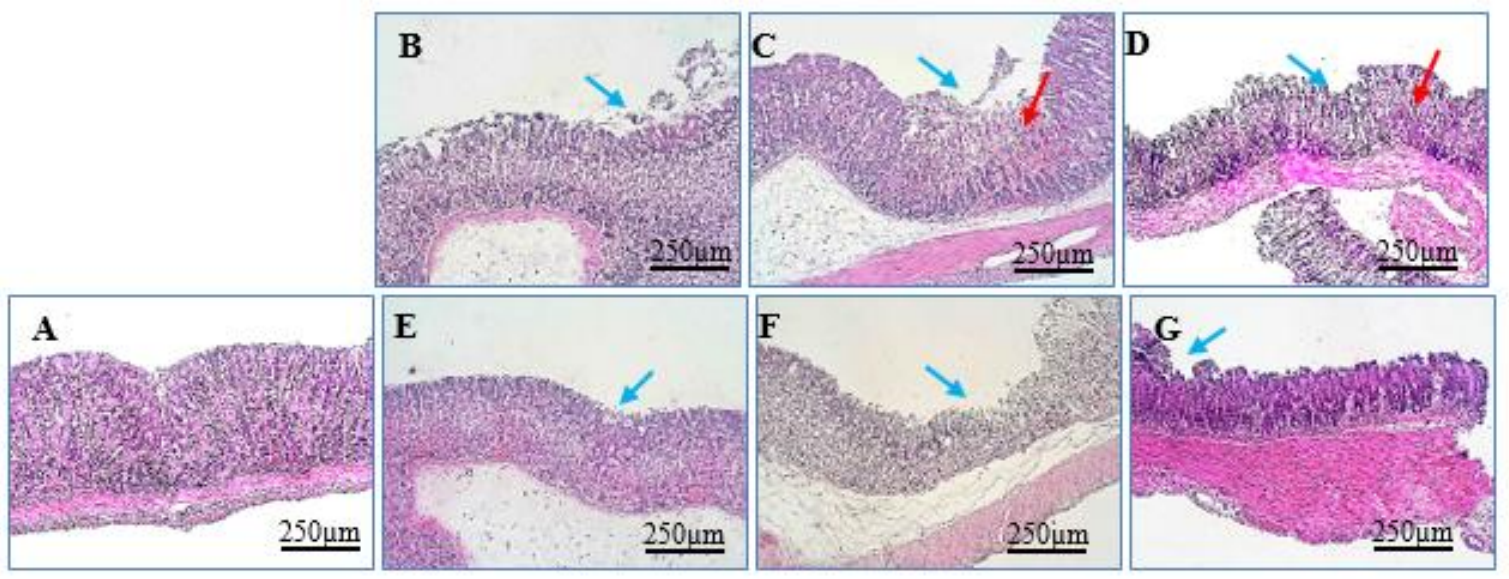

Hình 3. Mô học dạ dày chuột bị loét cấp tính do ethanol ở các nồng độ khác nhau và được bảo vệ bằng Omeprazole

A: ĐCSH; B: E60; C: E70; D: E80; E: E60+O; F: E70+O; G: E80+O; Mũi tên màu xanh: vị trí bong tróc và hoại tử niêm mạc dả dày, Mũi tên màu đỏ: vị trí xuất huyết.

\subsection{Mô hình viêm loét dạ dày bằng acetic acid}

Kết quả tổng độ acid của các nghiệm thức thử nghiệm loét dạ dày bằng acetic acid (Hình 3 ) cho thấy chuột cho uống acetic acid nồng độ 10\%, 15\% và $20 \%$ có tổng độ acid tăng dần theo nồng độ acid lần lượt $3,11 \pm 0,65 ; 5,23 \pm 0,88$ và $7,28 \pm 0,66 \mathrm{mEq} / \mathrm{L}$.
Trong đó, acetic acid $15 \%$ và $20 \%$ có tổng độ acid tăng cao khác biệt với nghiệm thức đối chứng sinh học $(\mathrm{p}<0,05)$. Khi có sử dụng Omeprazole, tổng độ acid của dạ dày chuột sử dụng acetic acid $15 \%$ và $20 \%$ khác biệt không có ý nghĩa so với đối chứng sinh học. Như vậy, đối với chỉ tiêu tổng độ acid, mô hình chuột uống acetic acid $15 \%$ và $20 \%$ có thể được sử dụng. 


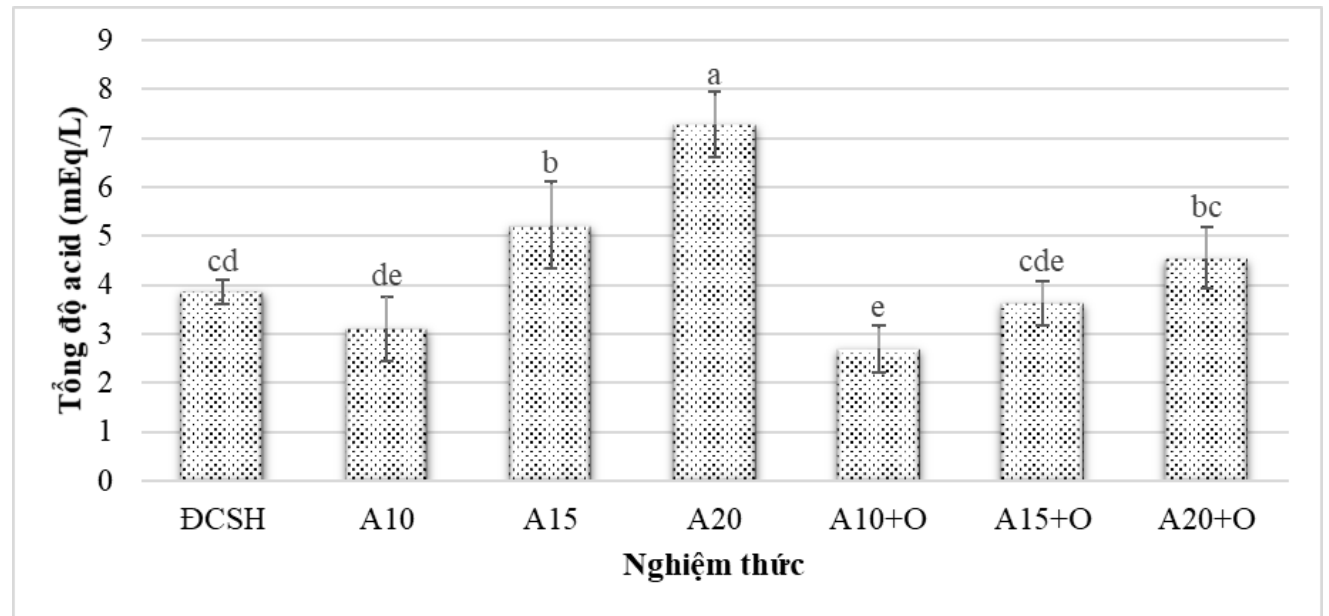

Hình 4. Chỉ số tổng độ acid của các nghiệm thức gây loét bằng acetic acid

Các cột trung bình \pm sai số chuẩn có các chũ cái giống nhau thì khác biệt không có ý nghĩa thống kê (Fisher, $p>0,05$ )

Mức độ loét dạ dày đánh giá qua các chỉ số loét (UI) cho thấy mức độ loét theo độ sâu nồng độ acid $10 \%$ và $15 \%$ thể hiện rõ sự khác biệt giữa nghiệm thức không được bảo vệ và được bảo vệ bằng Omeprazole (Bảng 3). Ở nồng độ acetic acid 20\%, Omeprazole mất tác dụng bảo vệ dạ dày, không có sự khác biệt giữa $\mathrm{A} 20$ và $\mathrm{A} 20+\mathrm{O}$. Kết hợp với kết quả giải phẫu cho thấy acetic acid gây loét, xuất huyết nặng và Omeprazole bị mất tác dụng bảo vệ dạ dày ở nồng độ thử nghiệm này (Hình 5). Vì thế nghiệm thức gây loét dạ dày bằng acetic acid $20 \%$ không phù hợp cho mô hình gây loét. Xét về hiệu suất bảo vệ dạ dày của Omeprazole đối với nghiệm thức uống acid $10 \%$ và $15 \%$ ở cả hiệu suất bảo vệ theo độ sâu, chiều dài và diện tích vết loét, chuột uống acid $10 \%$ có hiệu suất bảo vệ cao hơn so với chuột uống acid $15 \%$. Như vậy, nghiệm thức gây loét bằng acid $10 \%$ thể hiện rõ khả năng bảo vệ dạ dày của Omeprazole (đối chứng dương).

Bảng 3. Chỉ số loét và hiệu suất bảo vệ dạ dày gây ra bởi tác nhân gây loét acetic acid

\begin{tabular}{lrrrrrr}
\hline Lô & UISâu & $\begin{array}{r}\text { Hiệu suất } \\
\text { bảo vệ (Sâu) }\end{array}$ & UIDài & $\begin{array}{r}\text { Hiệu suất bảo } \\
\text { vệ (Dài) }\end{array}$ & UIDiện tích & $\begin{array}{r}\text { Hiệu suất bảo vệ } \\
\text { (Diện tích) }\end{array}$ \\
\hline $\mathrm{DCSH}$ & $0,00 \pm 0,00^{\mathrm{e}}$ & $100,00 \%$ & $0,00 \pm 0,00^{\mathrm{e}}$ & $100,00 \%$ & $0,00 \pm 0,00^{\mathrm{d}}$ & $100,00 \%$ \\
$\mathrm{~A} 10$ & $0,35 \pm 0,05^{\mathrm{c}}$ & - & $0,57 \pm 0,06^{\mathrm{b}, \mathrm{c}}$ & - & $33,91 \pm 15,06^{\mathrm{c}}$ & - \\
$\mathrm{A} 15$ & $0,48 \pm 0,03^{\mathrm{b}}$ & - & $0,67 \pm 0,06^{\mathrm{a}, \mathrm{b}}$ & - & $53,07 \pm 13,04^{\mathrm{b}}$ & - \\
$\mathrm{A} 20$ & $0,67 \pm 0,13^{\mathrm{a}}$ & - & $0,77 \pm 0,06^{\mathrm{a}}$ & - & $100,00 \pm 0,00^{\mathrm{a}}$ & - \\
$\mathrm{A} 10+\mathrm{O}$ & $0,15 \pm 0,00^{\mathrm{d}}$ & $57,14 \%$ & $0,43 \pm 0,06^{\mathrm{d}}$ & $24,56 \%$ & $2,5 \pm 1,04^{\mathrm{d}}$ & $92,63 \%$ \\
$\mathrm{~A} 15+\mathrm{O}$ & $0,32 \pm 0,14^{\mathrm{c}}$ & $33,33 \%$ & $0,53 \pm 0,12^{\mathrm{c}, \mathrm{d}}$ & $20,90 \%$ & $29,55 \pm 7,76^{\mathrm{c}}$ & $57,51 \%$ \\
$\mathrm{~A} 20+\mathrm{O}$ & $0,55 \pm 0,00^{\mathrm{a}, \mathrm{b}}$ & $17,91 \%$ & $0,70 \pm 0,00^{\mathrm{a}}$ & $9,10 \%$ & $96,02 \pm 1,43^{\mathrm{a}}$ & $3,98 \%$ \\
\hline
\end{tabular}

Ghi chú: Các trung bình độ lệch chuẩn có các chũ cái giống nhau trong cùng một cột thì khác biệt không có ý nghĩa thống kê (Fisher, $p>0$,05). Chú thích '- ' nghĩa là không sủ dụng chất bảo vệ dạ dày nên không tính toán hiệu suất bảo vệ.
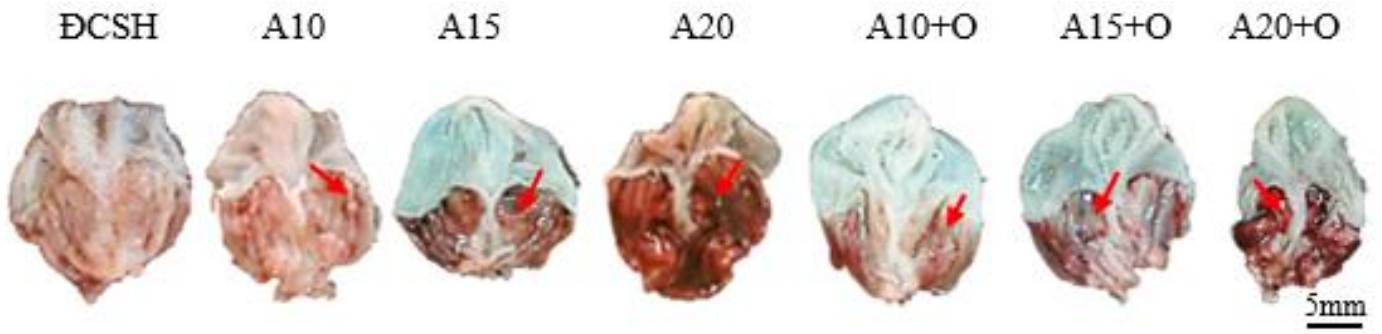

Hình 5. Hình thái dạy dày chuột bị loét cấp tính do acetic acid ở các nồng độ khác nhau và được bảo vệ bằng Omeprazol

Mũi tên màu đỏ: vị trí xuất huyết dạ dày. 
Quan sát mô dạ dày chuột gây loét bằng acetic acid cho thấy, acetic acid gây hoại tử lớp biểu mô dạ dày càng sâu về lớp cơ dạ dày theo sự gia tăng nồng độ của acid (Hình 6). Nghiệm thức chuột uống acid $20 \%$ gây loét sâu nhất, do đó, khi được bảo vệ bằng Omeprazole không thấy sự cải thiện về mức độ hoại tử biểu mô. Chuột uống acid $15 \%$, tế bào biểu mô vẫn bị hoại tử và loét sâu vào lớp tế bào dạ dày. Chuột uống acid $10 \%$, giảm số tế bào biểu mô bị hoại tử và sự bong tróc chỉ xuất hiện trên bề mặt biểu mô (Hình 6).

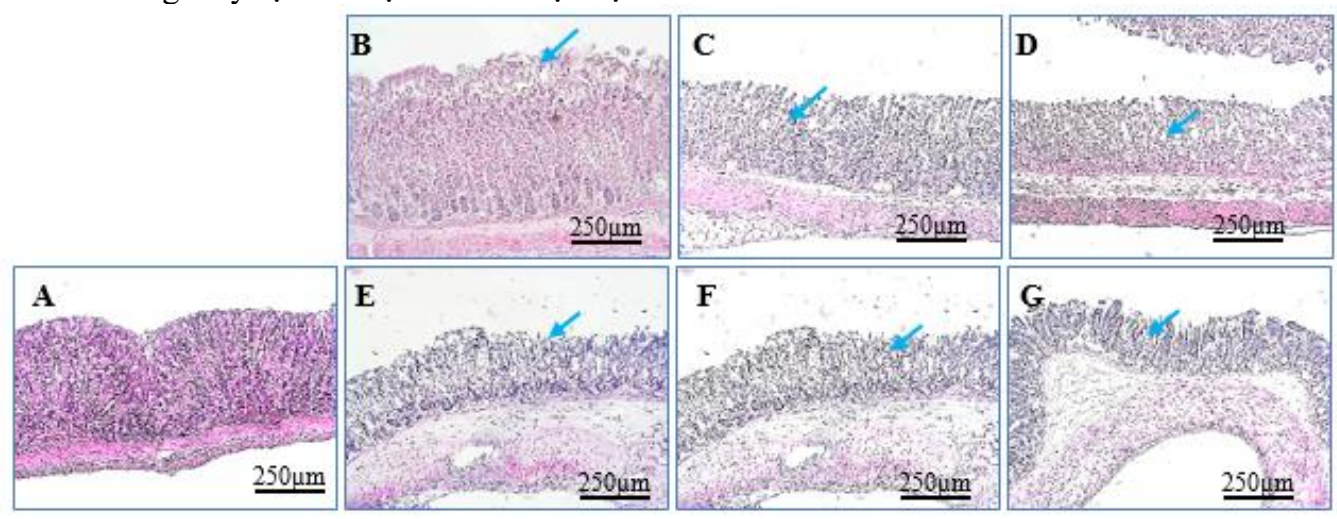

Hình 5. Hình thái dạy dày chuột bị loét cấp tính do acetic acid ở các nồng độ khác nhau và được bảo vệ bằng Omeprazol

\section{A: $D C S H ; B: A 10 ; C: A 15 ; D: A 20 ; E: A 10+O ; F: A 15+O ; G: A 20+O$.}

\subsection{Mô hình viêm loét dạ dày bằng Aspirin}

Aspirin là nguyên nhân phổ biến gây ra loét, ngay cả ở những bệnh nhân không bị nhiễm $H$. pylori (Gabriel, 1991). Khi sử dụng aspirin liều thấp (LDA) hàng ngày, tổn thương niêm mạc dạ dày xảy ra ở khoảng $40 \%-50 \%$ bệnh nhân; tăng nguy cơ xuất huyết dạ dày cũng được ghi nhận (Niv et al., 2005; Yeomans et al., 2005). Do đó, aspirin là nhân tố gây ra loét dạ dày do dùng thuốc kháng viêm không chứa steroid. Vì thế đề tài chọn aspirin làm tác nhân gây loét dạ dày cấp tính.

Aspirin gây tổn thương niêm mạc dạ dày do aspirin làm tăng nồng độ acid của dạ dày (Nishino et al., 2010). Kết quả xác định tổng độ acid cho thấy, các nghiệm thức chuột cho uống aspirin có tổng độ acid tăng so với nghiệm thức chuột uống nước cất $(\mathrm{p}<0,05)$. Trong các nghiệm thức gây loét dạ dày, nghiệm thức chuột uống aspirin nồng độ $350 \mathrm{mg} / \mathrm{kg}$ có tổng độ acid $(13,53 \pm 3,44 \mathrm{mEq} / \mathrm{L})$ cao hơn so với nghiệm thức $500 \mathrm{mg} / \mathrm{kg}(9,33 \pm 1,53 \mathrm{mEq} / \mathrm{L})$ và 650 $\mathrm{mg} / \mathrm{kg}(8,6 \pm 1,64 \mathrm{mEq} / \mathrm{L})(\mathrm{p}<0,05)$. Ở các nghiệm thức chuột uống aspirin được bảo vệ dạ dày bằng Omeprazole $(20 \mathrm{mg} / \mathrm{kg})$ có tổng độ acid giảm rõ rệt so với nghiệm thức không được bảo vệ $(\mathrm{p}<0,05)$. Do đó, cả nồng độ aspirin thử nghiệm $350 \mathrm{mg} / \mathrm{kg}$, $500 \mathrm{mg} / \mathrm{kg}$ và $650 \mathrm{mg} / \mathrm{kg}$ có thể được sử dụng thực hiện mô hình loét dạ dày.

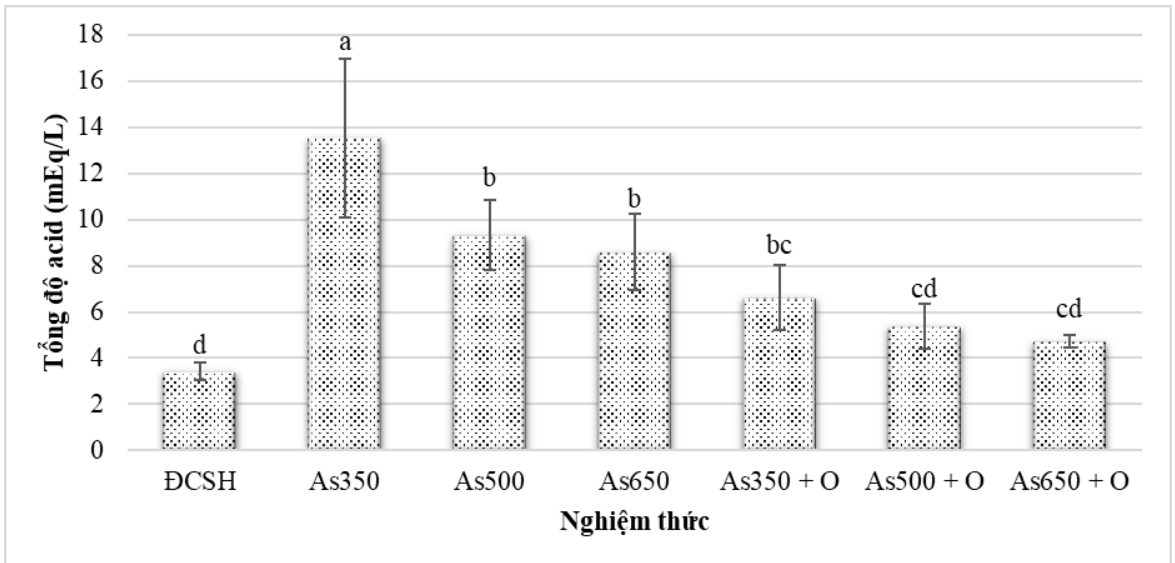

Hình 7. Đồ thị miêu tả sự khác biệt chỉ số tổng độ acid trung bình giữa các lô chuột

Các cột trung bình \pm sai số chuẩn có các ký tự giống nhau thì khác biệt không có ý nghĩa thống kê (Fisher, P<0,05). 
Omeprozole cho thấy khả năng bảo vệ dạ dày khi sử dụng aspirin ở các nồng độ. Cả 3 nghiệm thức chuột uống aspirin $350 \mathrm{mg} / \mathrm{kg}, 500 \mathrm{mg} / \mathrm{kg}, 650$ $\mathrm{mg} / \mathrm{kg}$ có chỉ số $\mathrm{UI}_{\text {Dài }}$ khác biệt với 3 nghiệm thức được bảo vệ bằng Omeprazole tương ứng. Chỉ số loét tính theo diện tích loét, nghiệm thức As 350 và As350+O không cho thấy sự khác biệt nhưng có sự khác biệt giữa nghiệm thức As500 và As650 với nghiệm thức được tương ứng có sử dụng Omeprazole. Như vậy, xét theo chỉ số loét UI, aspirin các nồng độ $500,650 \mathrm{mg} / \mathrm{kg}$ đều có thể sử dụng để xây dựng mô hình gây loét dạ dày do sử dụng thuốc chống viêm không steroid.

Bảng 4. Chỉ số loét và hiệu suất bảo vệ dạ dày gây ra bởi tác nhân gây loét Aspirin

\begin{tabular}{|c|c|c|c|c|c|c|}
\hline \multirow{2}{*}{ Lô } & \multirow{2}{*}{\multicolumn{2}{|c|}{$\begin{array}{c}\text { Hiệu suất } \\
\text { UISâu bảo vệ (Sâu) }\end{array}$}} & \multicolumn{2}{|c|}{ Diện tích bảo } & \multirow{2}{*}{ UIDiện tích } & \multirow{2}{*}{$\begin{array}{r}\text { Hiệu suất bảo vệ } \\
\text { (Diện tích) }\end{array}$} \\
\hline & & & $\mathbf{U I}_{\text {Dài }}$ & vệ (Dài) & & \\
\hline ĐCSH & $0,00 \pm 0,00^{\mathrm{d}}$ & $100,00 \%$ & $0,00 \pm 0,00^{\mathrm{c}}$ & $100,00 \%$ & $0,00 \pm 0,00^{\mathrm{b}}$ & $100,00 \%$ \\
\hline As350 & $0,15 \pm 0,10^{\mathrm{b}}$ & - & $0,30 \pm 0,21^{\mathrm{a}, \mathrm{b}}$ & - & $1,57 \pm 1,42^{b}$ & \\
\hline As500 & $0,23 \pm 0,08^{a, b}$ & - & $0,43 \pm 0,06^{\mathrm{a}}$ & - & $3,89 \pm 0,45^{\mathrm{a}}$ & \\
\hline As650 & $0,33 \pm 0,06^{a}$ & - & $0,50 \pm 0,00^{\mathrm{a}}$ & - & $5,36 \pm 1,29^{a}$ & \\
\hline As $350+O$ & $0,03 \pm 0,03^{\mathrm{c}, \mathrm{d}}$ & $88,89 \%$ & $0,00 \pm 0,00^{\mathrm{c}}$ & $100,00 \%$ & $0,00 \pm 0,00^{\mathrm{b}}$ & $89,18 \%$ \\
\hline As500+O & $0,13 \pm 0,09^{b, c}$ & $40,43 \%$ & $0,13 \pm 0,10^{\mathrm{b}, \mathrm{c}}$ & $69,77 \%$ & $0,34 \pm 0,60^{\mathrm{b}}$ & $84,49 \%$ \\
\hline As650+O & $0,13 \pm 0,05^{b, c}$ & $35,48 \%$ & $0,17 \pm 0,23^{\mathrm{b}, \mathrm{c}}$ & $66,00 \%$ & $0,69 \pm 1,19^{\mathrm{b}}$ & $53,19 \%$ \\
\hline
\end{tabular}

Ghi chú: Các trung bình士độ lệch chuẩn có các chũ cái giống nhau trong cùng một cột thì khác biệt không có ý nghĩa thống kê (Fisher, $p>0,05)$. Chú thích '- 'nghĩa là không sủ dụng chất bảo vệ dạ dày nên không tính toán hiệu suất bảo vệ.

Chuột gây loét dạ dày bằng Aspirin các nồng độ chỉ gây loét nhẹ ở một số vị trí, rất ít vị trí gây xuất huyết dạ dày. Do đó, ở nghiệm thức chuột uống aspirin khó xác định được độ sâu vết loét so với nghiệm thức 500 và $650 \mathrm{mg} / \mathrm{kg}$. Chuột uống Aspirin
$350 \mathrm{mg} / \mathrm{kg}+$ Omeprazole hầu như không còn vết gây loét dạ dày. Trong khi đó, chuột uống aspirin nồng độ $500 \mathrm{mg} / \mathrm{kg}$ + Omeprazole và $650 \mathrm{mg} / \mathrm{kg}$ + Omeprazole giảm loét khác biệt so với nghiệm thức không được bảo vệ bởi Omeprazole.

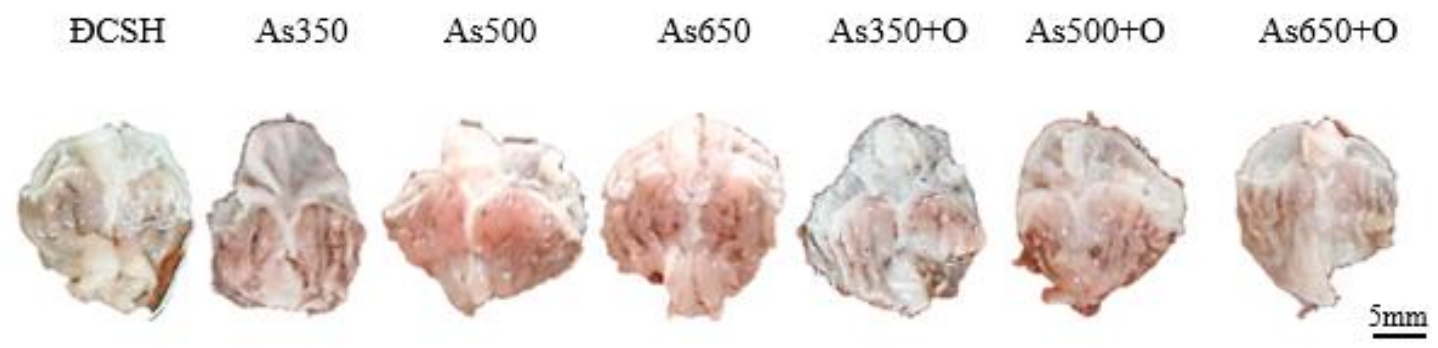

Hình 8. Hình thái dạy dày chuột bị loét cấp tính do aspirin ở các nồng độ khác nhau và được bảo vệ bằng Omeprazole

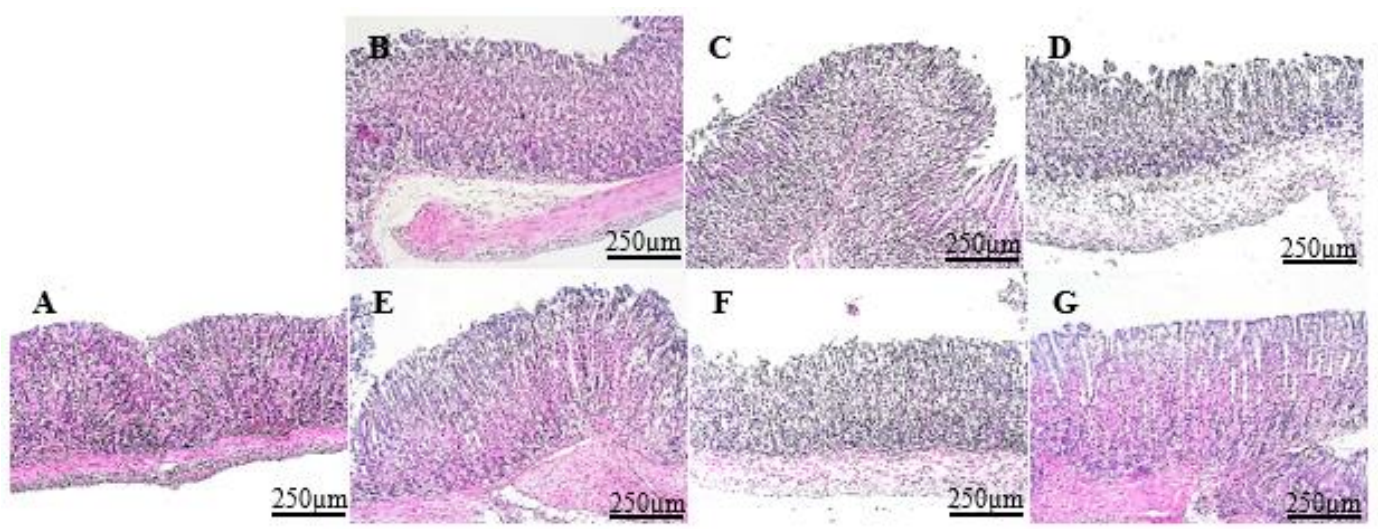

Hình 9. Hình thái dạy dày chuột bị loét cấp tính do aspirin ở các nồng độ khác nhau và được bảo vệ bằng Omeprazol

A: ĐCSH; B: As350; C: As500; D: As650; E: As350+O; F: As500+O; G:As650+O. 
Do aspirin ít gây loét dạ dày hơn so với các tác nhân gây loét ethanol hay acetic acid nên về mô học của dạ dày giữa nghiệm thức uống aspirin 350,500 và $650 \mathrm{mg} / \mathrm{kg}$ với nghiệm thức được bảo vệ bằng Omeprazole tương ứng khó tìm thấy sự khác biệt khi quan sát mô học (Hình 9). Trong quá trình bố trí thí nghiệm, tuy aspirin không gây loét và xuất huyết dạ dày ở mức độ cao nhưng aspirin có khả năng gây chết lên đến $50 \%$ chuột thí nghiệm ở liều $350 \mathrm{mg} / \mathrm{kg}$. Kết quả này cũng tương đồng với nghiên cứu trước đó của Bekemeier (1955). Do đó, tuy aspirin có thể sử dụng làm mô hình chuột viêm loét dạ dày như kết luận của Al-bayati et al. (2015), nhưng có thể cân nhắc khả năng gây chết chuột gây rủi ro cho các thí nghiệm.

\section{KẾT LUẬN}

Ethanol, acetic acid và aspirin đều có khả năng gây viêm loét dạ dày cấp tính. Viêm loét dạ dày do ethanol $70^{\circ}$ và acetic acid $15 \%$ cho mô hình chuột viêm loét dạ dày cao và phù hợp với việc sử dụng Omeprazole để làm đối chứng dương. aspirin có thể cân nhắc sử dụng vì có khả năng gây chết chuột thí nghiệm.

\section{LỜI CÁM ƠN}

Cám ơn quý thầy cô thuộc phòng thí nghiệm Sinh lý người và Động vật - Khoa Sư phạm đã tạo điều kiện nghiên cứu. Cám ơn Trường Đại học Cần Thơ đã hỗ trợ kinh phí cho nghiên cứu cấp trường cho sinh viên mã số TSV2020-128.

\section{TÀI LIỆU THAM KHẢO}

Abebaw, M., Mishra, B., \& Asmelashe, D. (2017).

Evaluation of anti-ulcer activity of the leaf extract of Osyris quadripartita Decne. (santalaceae) in rats. J. Exp. Pharmacol. 9, 1-11. 10.2147/JEP.S125383

Adefisayo, M.A., Akomolafe, R.O., Akinsomisoye, S.O., Alabi, Q.K., Ogundipe, O.L., Omole, J.G., \& Olamilosoye, K.P. (2017). Gastro-protective effect of methanol extract of Vernonia amygdalina (Del.) leaf on aspirin-induced gastric ulcer in Wistar rats. Toxicol Reports. 4 (2017), 625-633. https://doi.org/10.1016/j.toxrep.2017.11.004

Adinortey, M.B., Ansah, C., Galyuon, I., \& Nyarko, A. (2013). In vivo models used for evaluation of potential antigastroduodenal ulcer agents. Ulcers. 2013, 1-12. https://doi.org/10.1155/2013/796405

Ahmed, N., Ali Khan, M.S., Mat Jais, A.M., Mohtarrudin, N., Ranjbar, M., Amjad, M.S., Nagaraju, B., Faraz, M., Pathan, F., \& Chincholi, A. (2013). Anti-ulcer activity of sandalwood (Santalum album L.) stem hydro-alcoholic extract in three gastric-ulceration models of Wistar rats. Bol. Latinoam. y del Caribe Plantas Med. y Aromat., 12(1), 81-91.

Akre, K., Ekström, A.M., Signorello, L.B., Hansson, L.E., \& Nyrén, O. (2001). Aspirin and risk for gastric cancer: A population-based case-control study in Sweden. Br. J. Cancer., 84(7), 965-968. https://doi.org/10.1054/bjoc.2001.1702

Al-bayati, N.J., Ewadh, M.J., Ijam, A.H. (2015). Gastroprotective and antioxidant potential of Montelukast against acetyl salicylic acid induced gastric ulcer model in male rabbits. Int. J. Curr. Microbiol. Appl. Sci., 4(5), 80-89.

Al, I.A., Alhaider, A.A., Mossa, J.S., Al-sohaibani, M.O., Al-yahya, M.A., Rafatullah, S., \& Shaik, S.A. (2008). Gastroprotective effect of an aqueous suspension of Black Cumin Nigella sativa on necrotizing agents-Induced gastric injury in experimental animals. Saudi J. Gastroenterol., 14(3), 128-134. 10.4103/13193767.41731

Bộ Y Tế (2016). Huớng dẫn quy trình kỹ thuật chuyên ngành giải phẫu bệnh, tế bào học. Nxb Y học Hà Nội.

Chan, F.K.L., \& Leung, W.K. (2002). Peptic-ulcer disease. Lancet., 360, 933-941.

Chari, S., Teyssen, S., \& Singer, M. V. (1993). Alcohol and gastric acid secretion in humans. Gut., 34, 843-847. https://doi.org/10.1136/gut.34.6.843

Dashputre, N.L., \& Naikwade, N.S., 2011. Evaluation of anti-ulcer activity of methanolic extract of Abutilon indicum Linn leaves in experimental rats. Int. J. Pharm. Sci. Drug Res., 3(2), 97-100.

Gabriel, S.E., 1991. Risk for serious gastrointestinal complications related to use of nonsteroidal antiinflammatory drugs. Ann. Intern. Med., 115, 787-796. 10.7326/0003-4819-115-10-787

Goddard, A.F., \& Spiller, R.C. (1996). The effect of omeprazole on gastric juice viscosity, $\mathrm{pH}$ and bacterial counts. Aliment. Pharmacol. Ther., 10, 105-109. https://doi.org/10.1111/j.13652036.1996.tb00183.x

Goldstein, J.L., Lowry, S.C., Lanza, F.L., Schwartz, H.I., \& Dodge, W.E. (2006). The impact of lowdose aspirin on endoscopic gastric and duodenal ulcer rates in users of a non-selective nonsteroidal anti-inflammatory drug or a cyclooxygenase-2-selective inhibitor. Aliment. Pharmacol. Ther., 23, 1489-1498. https://doi.org/10.1111/j.13652036.2006.02912.x

Gul, H., Abbas, K., \& Qadir, M.I. (2015). Gastroprotective effect of ethanolic extract of Mentha longifolia in alcohol- and aspirin-induced gastric ulcer models. Bangladesh J. Pharmacol., 10, 
241-245.

https://doi.org/10.3329/bjp.v10i1.21689

Bekemeier, H. (1955). Salicylamide and salicylic acid poisoning in cats, in comparison with other animals [WWW Document].

https://chem.nlm.nih.gov/chemidplus/rn/50-78-2.

Jabeen, Q. (2018). Chemically-induced peptic ulcer: Gastroprotective effects of peach fruit. Curr. Trends Gastroenterol. Hepatol., 1, 22-30. https://doi.org/10.32474/CTGH.2018.01.000107

Kamarolzaman, M., Yahya, F., Mamet, S., Jakius, K., Mahmood, N., Shahril, M., Mohtarrudin, N., Suhaili, Z., \& Zakaria, Z. (2014).

Gastroprotective activity and mechanisms of action of Bauhinia purpurea Linn (Leguminoseae) leaf methanol extract. Trop. J. Pharm. Res., 13(11), 1889. https://doi.org/10.4314/tjpr.v13i11.17

Kim, S.-J., Kim, J.M., Shim, S.H., \& Chang, H.I. (2014). Anthocyanins accelerate the healing of naproxen-induced gastric ulcer in rats by activating antioxidant enzymes via modulation of Nrf2. J. Funct. Foods., 7, 569-579. https://doi.org/10.1016/j.jff.2013.12.028

Kim, Y.-S., Park, H.J., Kim, H., Song, J., \& Lee, D. (2019). Gastroprotective effects of Paeonia extract mixture HT074 against experimental gastric ulcers in rats. Evidence-Based Complement. Altern. Med. 2019, 1-13. https://doi.org/10.1155/2019/3546258

Madi, N., \& Abd al-Barr, A. (2014). Comparative evaluation of the gastroprotective effect of LCarnitine and Omeprazole on ethanol-induced gastric ulcer in male Albino Wister rats. Bull. Egypt. Soc. Physiol. Sci., 34(2), 293-309. https://doi.org/10.21608/besps.2014.34799

Nihar Ranjan, K., Shreechandan, P., Priyadarshini, P., \& Sabhya Sampad, S. (2017). Herbal drugs in treatment of peptic ulcer. J.Bio., 6(3), 499-508.

Nishino, M., Sugimoto, M., Kodaira, C., Yamade, M., Shirai, N., Ikuma, M., Tanaka, T., Sugimura, H., Hishida, A., \& Furuta, T. (2010). Relationship between low-dose aspirin-induced gastric mucosal injury and intragastric $\mathrm{pH}$ in healthy volunteers. Dig. Dis. Sci., 55, 16271636. https://doi.org/10.1007/s10620-009-0920-3

Niv, Y., Battler, A., Abuksis, G., Gal, E., Sapoznikov, B., \& Vilkin, A. (2005). Endoscopy in asymptomatic minidose aspirin consumers. Dig. Dis. Sci., 50(1), 78-80. https://doi.org/10.1007/s10620-005-1281-1

Oluwabunmi, I., \& Abiola, T. (2015). Gastroprotective effect of methanolic extract of Gomphrena celosioides on indomethacin induced gastric ulcer in Wistar albino rats. Int. J. Appl. Basic Med. Res., 5(1), 41-45. https://doi.org/10.4103/2229-516X.149238
Ozbakiş Dengiz, G., \& Gürsan, N. (2005). Effects of Momordica charantia L. (Cucurbitaceae) on indomethacin-induced ulcer model in rats. Turk. J. Gastroenterol., 16, 85-8.

Pöschl, G., \& Seitz, H.K. (2004). Alcohol and cancer. Alcohol \& Alcoholism., 39(3), 155-165. https://doi.org/10.1093/alcalc/agh057

Raeesi, M., Eskandari-Roozbahani, N., \& Shomali, T. (2019). Gastro-protective effect of Biebersteinia multifida root hydro-methanolic extract in rats with ethanol-induced peptic ulcer. Avicenna J. phytomedicine, 9(5), 410-418. https://doi.org/10.22038/ajp.2019.12902

Rahim, N.A., Hassandarvish, P., Golbabapour, S., Ismail, S., Tayyab, S., \& Abdulla, M.A. (2014). Gastroprotective effect of ethanolic extract of curcuma xanthorrhiza leaf against ethanolinduced gastric mucosal lesions in SpragueDawley rats. Biomed Res. Int. 2014, 1-12. https://doi.org/10.1155/2014/416409

Reddy, V.P., Sudheshna, G., S, K, A., Saran, S.S., Kumar, S.N., Ram, C.R., \& Reddy, K.R. (2012). Evaluation of anti-ulcer activity of Citrullus colocynthis fruit against pylorus ligation induced ulcers in male wistar rats. Int. J. Pharm. Pharm. Sci., 4, 446-451.

Ren, J.S., Kamangar, F., Forman, D., \& Islami, F. (2012). Pickled food and risk of gastric cancer A systematic review and meta-analysis of English and Chinese literature. Cancer Epidemiol. Biomarkers Prev., 21(6), 905-915. https://doi.org/10.1158/1055-9965.EPI-12-0202

Sattar, A., Abdo, A., Mushtaq, M.N., Anjum, I., \& Anjum, A. (2019). Evaluation of gastroprotective activity of Myristica fragrans on ethanol-induced ulcer in Albino rats. An. Acad. Bras. Cienc., 91(2), 1-8. https://doi.org/10.1590/0001-3765201920181044

Singer, M. V., Leffmann, C., Eysselein, V.E., Calden, H., \& Goebell, H. (1987). Action of ethanol and some alcoholic beverages on gastric acid secretion and release of gastrin in humans. Gastroenterology, 93(6), 1247-1254. https://doi.org/10.1016/0016-5085(87)90252-6

Somchit, M.N., Siti Rahmah, S., Zuraini, A., Ahmad Bustamam, A., Zakaria, Z.A., Somchit, N., \& Shamsuddin, L. (2007). Gastroprotective activity of Spirulina platensis in acetic acid and ethanol induced ulcers in rats. J. Nat. Remedies, 7, 3742. https://doi.org/10.18311/jnr/2007/192

Søreide, K., Thorsen, K., Harrison, E.M., Bingener, J., Møller, M.H., Ohene-Yeboah, M., \& Søreide, J.A. (2015). Perforated peptic ulcer. Lancet., 386, 1288-1298. https://doi.org/10.1016/S01406736(15)00276-7

Wariss, H.M., Mukhtar, M., Anjum, S., Bhatti, G.R., Pirzada, S.A., \& Alam, K. (2013). Floristic 
composition of the plants of the cholistan desert, Pakistan. Am. J. Plant Sci., 4(12), 58-65. https://doi.org/10.4236/ajps.2013.412A1009

Yeomans, N.D., Lanas, A.I., Talley, N.J., Thomson, A.B.R., Daneshjoo, R., Eriksson, B., AppelmanEszxzuk, S., Langstrom, G., Naesdal, J., Serrano, P., Singh, M., Skelly, M.M., \& Hawkey, C.J. (2005). Prevalence and incidence of gastroduodenal ulcers during treatment with vascular protective doses of aspirin. Aliment. Pharmacol. Ther., 22, 795-801. https://doi.org/10.1111/j.1365-

2036.2005.02649.x
Zelickson, M.S., Bronder, C.M., Johnson, B.L., Camunas, J.A., Smith, D.E., Rawlinson, D., Von, S., Stone, H.H., \& Taylor, S.M. (2011).

Helicobacter Pylori is not the predominant etiology for peptic ulcers requiring operation. Am. Surg., 77(8), 1054-1060. https://doi.org/10.1177/000313481107700827

Zittel, T.T., Jehle, E.C., \& Becker, H.D. (2000). Surgical management of peptic ulcer disease today - indication, technique and outcome. Langenbeck's Arch. Surg., 385, 84-96. https://doi.org/10.1007/s004230050250 